\title{
PENGARUH PENAMBAHAN ISOLAT PROTEIN KEDELAI TERHADAP KARAKTERISTIK KAMABOKO IKAN BARRAMUNDI (Lates calcalifer)
}

The Effect of Adding Soy Protein Isolate to the Characteristics of Kamaboko Barramundi Fish (Lates calcalifer)

\author{
Praniti Radya Andana Ilma ${ }^{1)}$, Komang Ayu Nocianitri ${ }^{2}$, Ni Made Indri Hapsari ${ }^{2)}$ \\ ${ }^{1}$ Mahasiswa Program Studi Ilmu dan Teknologi Pangan, Fakultas Teknologi Pertanian, Universitas Udayana \\ ${ }^{2}$ Dosen Program Studi Ilmu dan Teknologi Pangan, Fakultas Teknologi Pertanian, Universitas Udayana \\ Kampus Bukit Jimbaran, Badung-Bali
}

\begin{abstract}
The aim of this study was to know the effect of adding soy protein isolate (ISP) to the characteristics of kamaboko barramundi fish (Lates calcalifer) and to know the right addition of ISP that can produce kamaboko with the best characteristics. The study used a completely randomized design with the addition treatment of ISP that consists of 5 levels: 0\%, 4\%, 8\%, 12\%, and 16\%. The treatment was repeated 3 times to obtain 15 experimental units. The data was analyzed by variance and if it influential to the variable then continued with the Duncan test. The results showed that the addition of ISP on the producing of kamaboko had a highly significant effect to texture (gel strength), moisture content, protein content, ash content, hedonic test (color, texture, taste, overall acceptance) and scoring test (folding test and bite test). The addition of 12\% ISP produced kamaboko with the best characteristics with gel strength $1404.76 \mathrm{gf} / \mathrm{cm}^{2}$, water content $74.42 \%$, protein content $15.40 \%$, fat content $3.64 \%$, ash content $3.55 \%$, color, texture, taste, and overall acceptances were liked, aroma rather liked, appearance of meat without fiber and without foreign things, folding test does not crack if folded 4 times, and bite test rather strong specific product elasticity.
\end{abstract}

Keywords : soy protein isolate, barramundi fish, kamaboko, characteristics

\section{PENDAHULUAN}

Indonesia merupakan negara maritim yang mempunyai kekayaan sumber daya kelautan dan perikanan yang sangat melimpah. Produksi perikanan budidaya di Indonesia mengalami peningkatan dari tahun 2015 sebanyak 22,15 juta ton menjadi 23,1 juta ton pada tahun 2016. Nilai tersebut disumbangkan dari perikanan tangkap dan perikanan budidaya yang masing-masing menyumbangkan 6,83 juta ton dan 16,68 juta ton pada tahun 2016 (Anon., 2018a). Fillet ikan barramundi adalah salah satu fillet ikan yang permintaannya tinggi dan dapat dimanfaatkan menjadi produk olahan lanjutan yaitu kamaboko. Ikan barramundi mempunyai nilai ekonomis tinggi, baik untuk memenuhi

*Korespondesi Penulis:

E-mail: ilmadana15@gmail.com ${ }^{1)}$ kebutuhan konsumsi dalam negeri maupun luar negeri (Tarwiyah, 2001).

Kamaboko merupakan produk olahan ikan dari Jepang yang berbentuk gel, bersifat kenyal dan elastis (Park, 2005). Selain itu kamaboko juga merupakan produk precook yang praktis, tinggi protein dan rendah lemak, serta mudah disandingkan dengan makanan lain sebagai pendamping atau lauk (Anon., 2018b). Bahan baku yang digunakan pada pembuatan kamaboko adalah surimi atau daging ikan yang sudah dilumatkan. Ikan yang cocok diolah menjadi kamaboko adalah ikan yang berasal dari perairan dingin, berdaging putih, rendah lemak, dan tinggi protein. Proses selanjutnya adalah pemasakan dengan cara pengukusan, 
pemanggangan, perebusan maupun penggorengan (Suzuki, 1981). Hampir semua jenis ikan dapat dimanfaatkan sebagai bahan baku kamaboko, tetapi kekuatan gel atau kekenyalan dan elastisitasnya bervariasi menurut jenisnya. Berdasarkan kandungan protein dan lemaknya ikan barramundi termasuk ikan protein tinggi (15-20\%) dan kadar lemak rendah (5\%) serta mengandung 80,3\% air, 0\% karbohidrat, dan abu 1,1\% (Afrianto dan Liviawaty, 2005). Daging putih pada ikan barramundi memiliki kandungan protein (aktin dan miosin) yang lebih baik apabila dibandingkan dengan daging merah sehingga proses pembentukan gel akan lebih baik. Ikan dengan kandungan aktin dan miosin yang tinggi akan membentuk aktomiosin yang lebih banyak dan akan membentuk gel ketika proses pemanasan sehingga akan didapatkan tekstur yang kenyal (Pradana, 2008).

Kamaboko berbentuk emulsi padat, di mana fase zat cair terdispersi dalam fase zat padat. Sifat fisikokimia yang penting dari kamaboko adalah terbentuknya matrik gel yang kohesif dan kokoh, memiliki tekstur yang kenyal, serta struktur yang kompak dan juicy (Lanier, 1992). Kestabilan emulsi perlu dipertahankan karena menjadi kriteria terpenting dalam pembuatan kamaboko (Fennema, 1976).

Kamaboko dapat mengalami pemecahan emulsi pada saat pengolahan (Utomo, 2014), sehingga perlu dilakukan penambahan emulsifier. Menurut Latifa (2014) telur merupakan emulsifier yang umum digunakan untuk menstabilkan emulsi, akan tetapi kekuatan gel dan kandungan protein yang dihasilkan pada produk surimi ikan kurisi masih kurang apabila dibandingkan dengan emulsifier lain. Salah satu alternatif emulsifier yang dapat digunakan adalah isolat protein kedelai atau Soy Protein Isolate (ISP).

ISP adalah bentuk halus kedelai yang mengandung $90 \%$ protein kedelai yang mampu memperbaiki sifat emulsi, meningkatkan cita rasa, dan memberikan tekstur yang kenyal (Suryanto, 2011). Penggunaan ISP biasanya sebagai bahan campuran dalam makanan olahan daging dan susu (Koswara, 2009).

Penelitian yang dilakukan Astuti (2014) menunjukkan bahwa penambahan ISP 7\% pada pengolahan bakso dari surimi ikan swagi menghasilkan karakteristik terbaik dengan kekuatan gel 1229,19 gf, kadar air 55,6 \% dan kadar protein 20,2\%. Menurut Latifa (2014) kualitas gel surimi ikan kurisi dapat dipengaruhi oleh jenis dan konsentrasi bahan tambahan yang digunakan, berdasarkan hasil penelitian tersebut penambahan ISP $12 \%$ merupakan bahan tambahan yang lebih baik apabila dibandingkan dengan penambahan karaginan 3\% serta penambahan white egg powder $2 \%$. Penambahan ISP 12\% menghasilkan kekuatan gel sebesar 1275,47 g.cm dan kandungan protein $19,39 \%$.

Berdasarkan uraian tersebut maka dilakukan penelitian ini untuk mengetahui berapa penambahan ISP yang tepat agar dihasilkan kamaboko ikan barramundi dengan karakterisktik terbaik.

\section{METODE PENELITIAN}

\section{Tempat dan Waktu}

Penelitian ini dilaksanakan di Laboratorium Pengolahan Pangan, Laboratorium Analisis Pangan, dan Laboratorium Teknik Pasca Panen, Fakultas Teknologi Pertanian, Universitas Udayana. Penelitian ini dilakukan pada bulan Oktober 2018 sampai Desember 2018.

\section{Bahan dan Alat}

Bahan yang digunakan dalam pembuatan kamaboko adalah daging ikan barramundi yang diperoleh dari PT. I AM BE U MINA UTAMA Denpasar, Isolat Protein Kedelai dari toko online 
casingsosis di Subang, garam, dan gula, sedangkan bahan analisis antara lain: aquades, $\mathrm{H}_{2} \mathrm{SO}_{4}, \mathrm{NaOH} 50 \%$, HCl, tablet Kjeldahl, asam borat, indikator PP, dan heksan.

Alat untuk analisis karakteristik kimia dan fisik kamaboko ikan barramundi adalah lumpang, timbangan analitik (Shimadzu), aluminium foil, oven, desikator, cawan aluminium, cawan porselin, muffle (Daihan), erlenmeyer (pyrex), pipet volume (pyrex), tabung reaksi (Pyrex), spatula, pinset, gelas ukur (pyrex), gelas beaker (pyrex), kertas saring, tekstur analyzer (Brookefield), dan kertas label. Alat-alat yang digunakan untuk pembuatan produk antara lain: grinder daging (Miyako), gelas ukur, baskom, timbangan, kompor gas, kain blacu, cetakan kamaboko, dan kukusan.

\section{Rancangan Percobaan}

Rancangan percobaan yang digunakan pada penelitian ini adalah Rancangan Acak Lengkap (RAL) dengan perlakuan penambahan ISP yang digunakan pada pembuatan kamaboko yang terdiri dari 5 taraf yaitu: K0 (Penambahan ISP 0\%), K1 (Penambahan ISP 4\%), K2 (Penambahan ISP 8\%), K3 (Penambahan ISP 12\%), K4 (Penambahan ISP 16\%).

Masing-masing perlakuan diulang sebanyak 3 kali sehingga diperoleh 15 unit percobaan. Data yang diperoleh dianalisis dengan sidik ragam dan apabila perlakuan berpengaruh terhadap variabel yang diamati maka dilanjutkan dengan uji Duncan (Steel dan Torrie, 1993).

\section{Pelaksanaan Penelitian}

Penelitian ini diawali dengan preparasi daging ikan barramundi yang akan diolah menjadi kamaboko. Disiapkan fillet ikan barramundi yang sebelumnya sudah dicuci bersih, daging yang sudah dicuci dibekukan selama 24 jam dengan suhu maksimal $-18^{\circ} \mathrm{C}$. Setelah beku daging dihancurkan menggunakan grinder sampai halus, lumatan daging yang diperoleh kemudian dicuci dan direndam dalam air dingin pada suhu $0-10^{\circ} \mathrm{C}$ selama $10-15$ menit sampai tidak ada gumpalan daging lumat dan diulang sebanyak 3 kali. Proses pencucian terakhir dilakukan dengan penambahan garam sebanyak $0,3 \%$ yang bertujuan untuk mempercepat pengurangan air, penghilangan lendir, darah dan kotoran lain dari daging ikan, dan selama proses pencucian dilakukan proses pengadukan. Perbandingan daging ikan dengan air adalah sebanyak 1:4.

Setelah pencucian selesai dilakukan proses penyaringan (straining) dan pengurangan air dengan cara mengepres daging lumat hasil pencucian dengan kain blacu dan dilakukan pemisahan dari duri ataupun urat ikan sampai diperoleh lumatan yang halus. Lumatan daging yang sudah dipres ditambahkan ISP dengan jumlah sesuai perlakuan $(0 \%, 4 \%, 8 \%, 12 \%$, dan $16 \%$ ) kemudian ditambahkan gula sebanyak 3\% dan garam 3\% pada lumatan daging, kemudian dimasukkan pada cetakan kamaboko untuk dikukus pada suhu $40^{\circ} \mathrm{C}$ selama 30 menit kemudian suhunya dinaikkan sampai $90^{\circ} \mathrm{C}$ selama 20 menit. Setelah pengukusan, kamaboko didinginkan dengan air es bersuhu $\leq$ $5^{\circ} \mathrm{C}$ selama 10-15 menit (Anon., 2013) yang dimodifikasi.

\section{Variabel yang Diamati}

Variabel yang diamati dalam penelitian ini meliputi kekuatan gel (Midayanto dan Yuwono, 2014), kadar air dengan metode pengeringan, kadar protein dengan metode Mikro-Kjeldahl, kadar lemak dengan metode soxhlet, kadar abu dengan metode pengabuan kering (Sudarmadji et al., 1997) dan pengujian hedonik mengenai warna, aroma, tekstur, rasa, dan penerimaan keseluruhan produk kamaboko ikan barramundi (Soekarto,1985) serta pengujian sensoris skoring yang meliputi kenampakan, uji lipat, dan uji gigit yang mengacu pada SNI 2694:2013. 


\section{HASIL DAN PEMBAHASAN}

Hasil analisis kekuatan gel, kadar air, kadar protein, kadar lemak dan kadar abu kamaboko ikan barrramundi dengan penambahan ISP dapat dilihat pada Tabel 1.

\section{Kekuatan Gel}

Hasil sidik ragam menunjukkan bahwa penambahan ISP berpengaruh sangat nyata $(\mathrm{P}<0,01)$ terhadap kekuatan gel kamaboko ikan barramundi. Tabel 1 menunjukkan nilai rata-rata terendah didapatkan pada perlakuan K0 (0\%) yaitu $349,73 \mathrm{gf} / \mathrm{cm}^{2}$, sedangkan kekuatan gel tertinggi didapatkan pada perlakuan K3 (12\%) yaitu 1404,76 gf/ $\mathrm{cm}^{2}$. Berdasarkan Tabel 1 maka perlakuan $\mathrm{K} 2$, K3, dan $\mathrm{K} 4$ (penambahan ISP $8 \%, 12 \%$, dan $16 \%$ ) pada pembuatan kamaboko ikan barramundi sudah memenuhi persyaratan SNI 2694:2013 dengan nilai kekuatan gel minimal $600 \mathrm{gf} / \mathrm{cm}^{2}$.

Semakin tinggi penambahan ISP (sampai penambahan 12\%) maka kekuatan gel kamaboko ikan barramundi akan mengalami kenaikan karena kadar air pada produk akan semakin rendah, hal ini karena jumlah ISP yang ditambahkan lebih banyak sehingga jumlah air menjadi berkurang. Semakin banyak penambahan ISP maka kandungan protein pada produk juga akan meningkat, pada saat proses pemanasan terjadi proses koagulasi protein yang membuat kekuatan gel produk juga akan lebih baik, akan tetapi penambahan ISP yang berlebih akan menimbulkan penghambatan cross-linking dari protein miofibril sehingga kekuatan gel nya menurun (Astuti, 2014). Menurut Chung dan Lee (1991), penurunan nilai kekuatan gel terjadi karena protein non-otot mengganggu pembentukan gel dengan mencegah aktomiosin berikatan.

Hal tersebut sesuai dengan penelitian Jafarpour et al., (2012) yang meneliti tentang surimi ikan mas dengan penambahan ISP $10 \%$, $20 \%$, dan $30 \%$ dengan nilai kekuatan gel masing-masing yaitu 1241,52 gf, 969,80 gf, dan 775,27 gf, sehingga dapat disimpulkan bahwa penambahan ISP dapat meningkatkan kekuatan gel dan bila terlalu banyak dapat menurunkan nilai kekuatan gel.

\section{Kadar Air}

Hasil sidik ragam menunjukkan bahwa penambahan ISP berpengaruh sangat nyata $(\mathrm{P}<0,01)$ terhadap kadar air kamaboko. Tabel 1 menunjukkan nilai rata-rata kadar air terendah kamaboko didapatkan pada perlakuan K4 yaitu $72,42 \%$, sedangkan kadar air tertinggi didapatkan pada perlakuan K0 yaitu $83,56 \%$. Hal ini menunjukkan bahwa semakin tinggi penambahan ISP maka kadar air kamaboko akan semakin berkurang.

Tabel 1. Nilai rata-rata hasil analisis tekstur, kadar air, kadar protein, kadar lemak, dan kadar abu kamaboko

\begin{tabular}{llcccc}
\hline $\begin{array}{c}\text { Penambahan } \\
\text { ISP }\end{array}$ & $\begin{array}{c}\text { Tekstur/ Kekuatan Gel } \\
\left(\mathrm{gf} / \mathrm{cm}^{2}\right)\end{array}$ & $\begin{array}{c}\text { Kadar } \\
\text { Air }(\%)\end{array}$ & $\begin{array}{c}\text { Kadar Protein } \\
(\%)\end{array}$ & $\begin{array}{c}\text { Kadar Lemak } \\
(\%)\end{array}$ & Kadar Abu (\%) \\
\hline K0 $(0 \%)$ & $349,73 \pm 25,80 \mathrm{e}$ & $83,56 \pm 0,08 \mathrm{a}$ & $7,55 \pm 0,25 \mathrm{e}$ & $3,82 \pm 0,23 \mathrm{a}$ & $3,11 \pm 0,06 \mathrm{~b}$ \\
K1 $(4 \%)$ & $534,89 \pm 53,11 \mathrm{~d}$ & $80,57 \pm 0,02 \mathrm{~b}$ & $9,62 \pm 0,39 \mathrm{~d}$ & $3,81 \pm 0,37 \mathrm{a}$ & $3,21 \pm 0,10 \mathrm{~b}$ \\
K2 $(8 \%)$ & $857,34 \pm 65,05 \mathrm{c}$ & $78,38 \pm 0,09 \mathrm{c}$ & $12,20 \pm 0,21 \mathrm{c}$ & $3,79 \pm 0,31 \mathrm{a}$ & $3,14 \pm 0,26 \mathrm{~b}$ \\
K3 $(12 \%)$ & $1404,76 \pm 112,49 \mathrm{a}$ & $74,42 \pm 0,27 \mathrm{~d}$ & $15,40 \pm 0,52 \mathrm{~b}$ & $3,64 \pm 0,09 \mathrm{a}$ & $3,55 \pm 0,12 \mathrm{a}$ \\
K4 $(16 \%)$ & $1134,23 \pm 77,77 \mathrm{~b}$ & $72,42 \pm 0,13 \mathrm{e}$ & $17,55 \pm 0,52 \mathrm{a}$ & $3,49 \pm 0,05 \mathrm{a}$ & $3,71 \pm 0,25 \mathrm{a}$ \\
\hline
\end{tabular}

Keterangan: Huruf yang sama dibelakang nilai rata-rata pada kolom yang sama menunjukkan perlakuan berbeda tidak nyata $(\mathrm{P}>0,05)$. 
Menurut SNI 2694:2013 kadar air maksimal pada surimi adalah $80 \%$, sehingga kamaboko ikan barramundi dengan penambahan ISP $8 \%$, $12 \%$, dan $16 \%$ sudah memenuhi SNI dengan nilai rata-rata kadar air sebesar 78,38\%, 74,42\%, dan $72,42 \%$.

Penurunan kadar air pada produk kamaboko disebabkan oleh pengaruh panambahan ISP, jumlah padatan akan lebih banyak sehingga jumlah air menjadi berkurang. Semakin tinggi penambahan ISP maka kadar air akan semakin rendah. ISP memiliki kadar air yang rendah yaitu $5,91 \%$ (Widodo,2008) dan memiliki kemampuan menstabilkan emulsi, serta membantu mempertahankan struktur pada produk olahan daging (Koswara, 2009). Kemampuan pembentukan gel pada daging ikan disebabkan oleh aktomiosin yang merupakan komponen utama dari miofibril (Latifa, 2014).

\section{Kadar Protein}

Hasil analisis sidik ragam menunjukkan bahwa penambahan ISP berpengaruh sangat nyata $(\mathrm{P}<0,01)$ terhadap kadar protein kamaboko ikan barramundi. Tabel 1 menunjukkan nilai kadar protein terendah diperoleh pada perlakuan K0 yaitu $7,55 \%$ dan kadar protein tertinggi pada perlakuan K4 yaitu $17,55 \%$. Hal tersebut menunjukkan bahwa semakin tinggi penambahan ISP maka kadar protein juga akan meningkat karena kandungan protein ISP dapat mencapai 90-95\%. Berdasarkan data pada Tabel 1, kamaboko ikan barramundi dengan penambahan ISP $8 \%, 12 \%$, dan 16\% sudah memenuhi SNI 2694:2013 tentang persyaratan mutu dan keamanan surimi dengan kadar protein minimal $12 \%$. Peningkatan kadar protein pada surimi dipengaruhi oleh ISP yang ditambahkan, sehingga semakin tinggi penambakan ISP maka kadar protein juga akan semakin meningkat.

\section{Kadar Lemak}

Hasil sidik ragam menunjukkan bahwa penambahan ISP berpengaruh tidak nyata terhadap kadar lemak kamaboko $(\mathrm{P}>0,05)$. Tabel 1 menunjukkan nilai rata-rata kadar lemak kamaboko berkisar antara 3,49\% sampai 3,82\% dan berbeda tidak nyata pada masing-masing perlakuan. Hal ini menunjukkan bahwa penambahan ISP tidak mempengaruhi kadar lemak kamaboko ikan barramundi. Standar kadar lemak pada kamaboko tidak tercantum pada SNI 2694:2013.

\section{Kadar Abu}

Hasil sidik ragam menunjukkan bahwa penambahan ISP berpengaruh sangat nyata terhadap kadar abu kamaboko $(\mathrm{P}<0,01)$. Tabel 1 menunjukkan nilai rata-rata kadar abu terendah kamaboko didapatkan pada perlakuan K0 yaitu $3,11 \%$, sedangkan kadar abu tertinggi didapatkan pada perlakuan K4 yaitu 3,71\%. Kamaboko dengan perlakuan penambahan ISP $0 \%, 4 \%$, dan $8 \%$ berbeda tidak nyata akan tetapi berbeda nyata dengan perlakuan penambahan ISP $12 \%$ dan $16 \%$. Standar kadar abu pada kamaboko tidak tercantum pada SNI 2694:2013.

Hal ini menunjukkan bahwa semakin tinggi penambahan ISP maka kadar abu kamaboko akan semakin meningkat, kandungan abu pada ISP adalah 0,87\%, selain itu kandungan abu pada ikan barramundi dan bahan tambahan lain seperti gula dan garam juga mempengaruhi peningkatan kadar abu kamaboko ikan barramundi. Kadar abu daging berhubungan erat dengan kadar air dan kadar protein pada suatu jaringan bebas lemak (Forrest et al., 1975). Sebagian besar bahan makanan, yaitu sekitar $96 \%$ terdiri dari bahan organik dan air, sisanya terdiri dari unsur-unsur mineral. Unsur mineral juga dikenal sebagai zat anorganik atau kadar abu, karena dalam proses pembakaran, bahan-bahan organik akan terbakar 
habis, sedangkan bahan anorganik tidak habis terbakar (Winarno, 1997).

\section{Evaluasi Sensoris}

Evaluasi sensoris kamaboko dilakukan dengan uji hedonik terhadap warna, aroma, tekstur, rasa, dan penerimaan keseluruhan kamaboko serta uji skoring terhadap kenampakan, uji lipat, dan uji gigit kamaboko. Nilai rata-rata uji hedonik terhadap warna, aroma, tekstur, rasa, dan penerimaan keseluruhan kamaboko dapat dilihat pada Tabel 2 , serta nilai rata-rata uji skoring terhadap kenampakan, uji lipat, dan uji gigit kamaboko dapat dilihat pada pada Tabel 3.

\section{Warna}

Hasil sidik ragam menunjukkan bahwa penambahan ISP pada kamaboko ikan barramundi berpengaruh sangat nyata $(\mathrm{P}<0,01)$ terhadap uji hedonik warna kamaboko ikan barramundi. Tabel 2 menunjukkan bahwa nilai rata-rata tertinggi diperoleh pada perlakuan $\mathrm{K} 2$ $(6,07)$ dan berbeda tidak nyata dengan K1 $(5,53)$ dan K3 $(5,73)$ dengan kriteria suka, sedangkan nilai rata-rata terendah diperoleh pada perlakuan K4 $(4,47)$ dan berbeda tidak nyata dengan K0 $(4,53)$ dengan kriteria agak suka.

Warna merupakan komponen yang sangat penting untuk menentukan kualitas atau derajat penerimaan suatu bahan pangan. Penentuan mutu suatu bahan pangan pada umumnya tergantung pada warna karena warna tampil terlebih dahulu (Winarno, 2004).

\section{Aroma}

Hasil sidik ragam menunjukkan bahwa penambahan ISP berpengaruh tidak nyata pada aroma kamaboko ikan barramundi $(\mathrm{P}>0,05)$. Tabel 2 menunjukkan bahwa nilai rata-rata uji hedonik aroma kamaboko ikan barramundi berkisar antara 4,47 dengan kriteria biasa sampai dengan 5,40 dengan kriteria agak suka dan semua perlakuan berbeda tidak nyata. Hal ini menunjukkan bahwa penambahan ISP tidak mempengaruhi aroma kamaboko ikan barramundi.

\section{Tekstur}

Hasil sidik ragam menunjukkan bahwa penambahan ISP pada pembuatan kamaboko ikan barramundi berpengaruh sangat nyata $(\mathrm{P}<0,01)$ terhadap uji hedonik tekstur dari kamaboko ikan barramundi. Tabel 2 menunjukkan nilai rata-rata uji hedonik tekstur kamaboko tertinggi diperoleh pada perlakuan K2 $(6,13)$ dan berbeda tidak nyata dengan K3 $(5,53)$ dengan kriteria suka sedangkan rata-rata terendah diperoleh $\mathrm{K} 0(2,87)$ dengan kriteria agak tidak suka.

Hasil yang didapat dari pengujian hedonik sesuai dengan pengujian tekstur (kekuatan gel) menggunakan texture analyzer. Semakin tinggi penambahan ISP maka tekstur semakin baik dan semakin disukai panelis, akan tetapi penambahan ISP K4 (16\%) menghasilkan tekstur yang sangat kompak sehingga tidak terlalu disukai penelis.

\section{Rasa}

Hasil sidik ragam menunjukkan bahwa penambahan ISP berpengaruh sangat nyata $(\mathrm{P}<0,01)$ terhadap uji hedonik rasa kamaboko ikan barramundi. Nilai rata-rata dari uji hedonik rasa pada Tabel 2 menunjukkan bahwa nilai ratarata tertinggi diperoleh pada kamaboko perlakuan K2 $(5,93)$ dan K3 $(5,93)$ dengan kriteria suka serta berbeda tidak nyata dengan K4 $(5,13)$ sedangkan nilai rata-rata terendah diperoleh kamaboko perlakuan K0 $(3,60)$ dengan kriteria biasa.

Perbedaan rasa disebabkan karena penambahan ISP yang dapat mempengaruhi rasa kamaboko yang dihasilkan. Menurut Sari (2016) bahan makanan merupakan salah satu faktor penentu cita rasa makanan. Makanan yang 
Tabel 2. Nilai rata-rata uji hedonik warna, aroma, dan tekstur kamaboko

\begin{tabular}{lllllc}
\hline Penambahan & \multicolumn{5}{c}{ Nilai Rata-Rata Uji Hedonik } \\
\cline { 2 - 5 } ISP & Warna & Aroma & Tekstur & Rasa & Penerimaan Keseluruhan \\
\hline K0 $(0 \%)$ & $4,53 \pm 1,18 \mathrm{~b}$ & $4,47 \pm 1,30 \mathrm{a}$ & $2,87 \pm 1,06 \mathrm{~d}$ & $3,60 \pm 1,55 \mathrm{c}$ & $3,67 \pm 0,90 \mathrm{~d}$ \\
K1 $(4 \%)$ & $5,53 \pm 1,00 \mathrm{a}$ & $4,87 \pm 1,12 \mathrm{a}$ & $5,07 \pm 1,03 \mathrm{bc}$ & $5,00 \pm 1,00 \mathrm{~b}$ & $5,20 \pm 0,86 \mathrm{bc}$ \\
K2 $(8 \%)$ & $6,07 \pm 0,45 \mathrm{a}$ & $5,40 \pm 1,18 \mathrm{a}$ & $6,13 \pm 0,74 \mathrm{a}$ & $5,93 \pm 0,80 \mathrm{a}$ & $5,93 \pm 0,70 \mathrm{a}$ \\
K3 $(12 \%)$ & $5,73 \pm 0,80 \mathrm{a}$ & $5,40 \pm 1,30 \mathrm{a}$ & $5,53 \pm 1,06 \mathrm{ab}$ & $5,93 \pm 0,88 \mathrm{a}$ & $5,67 \pm 0,72 \mathrm{ab}$ \\
K4 $(16 \%)$ & $4,47 \pm 1,45 \mathrm{~b}$ & $5,27 \pm 1,03 \mathrm{a}$ & $4,47 \pm 1,30 \mathrm{c}$ & $5,13 \pm 1,18 \mathrm{ab}$ & $4,80 \pm 1,14 \mathrm{c}$ \\
\hline
\end{tabular}

Keterangan: Huruf yang sama dibelakang nilai rata-rata pada kolom yang sama menunjukkan perlakuan berbeda tidak nyata $(\mathrm{P}>0,05)$.

Kriteria hedonik: 1 (sangat tidak suka), 2 (tidak suka), 3 (agak tidak suka), 4 (biasa), 5 (agak suka), 6 (suka), 7 (sangat suka).

Tabel 3. Nilai rata-rata uji skoring kenampakan, uji lipat, dan uji gigit kamaboko.

\begin{tabular}{llll}
\hline \multirow{2}{*}{ Penambahan ISP } & \multicolumn{3}{c}{ Nilai Rata-Rata Uji Skoring Kamaboko } \\
\cline { 2 - 4 } & Kenampakan & Uji Lipat & Uji Gigit \\
\hline K0 $(0 \%)$ & $8,60 \pm 1,12 \mathrm{a}$ & $1,27 \pm 0,70 \mathrm{~d}$ & $2,20 \pm 1,48 \mathrm{~d}$ \\
K1 $(4 \%)$ & $8,87 \pm 0,52 \mathrm{a}$ & $5,93 \pm 2,60 \mathrm{c}$ & $5,00 \pm 1,30 \mathrm{c}$ \\
K2 $(8 \%)$ & $8,73 \pm 0,70 \mathrm{a}$ & $7,53 \pm 1,77 \mathrm{~b}$ & $6,60 \pm 1,12 \mathrm{~b}$ \\
K3 $(12 \%)$ & $8,60 \pm 1,12 \mathrm{a}$ & $8,07 \pm 1,48 \mathrm{ab}$ & $7,40 \pm 0,82 \mathrm{~b}$ \\
K4 $(16 \%)$ & $8,47 \pm 1,60 \mathrm{a}$ & $8,87 \pm 0,52 \mathrm{a}$ & $8,87 \pm 0,52 \mathrm{a}$ \\
\hline
\end{tabular}

Keterangan: Huruf yang sama dibelakang nilai rata-rata pada kolom yang sama menunjukkan perlakuan berbeda tidak nyata $(\mathrm{P}>0,05)$.

Kriteria skoring:

a. Kenampakan: 1 (daging sangat banyak serat, ada benda asing), 3 (daging banyak serat, ada benda asing), 5 (daging agak banyak serat, ada benda asing), 7 (daging sedikit serat, tanpa benda asing), 9 (daging tanpa serat, tanpa benda asing).

b. Uji lipat: 1 (patah seluruhnya bila dilipat 2), 3 (retak tetapi masih menyatu bila dilipat 2), 5 (sedikit retak bila dilipat 2), 7 (sedikit retak bila dilipat 4), 9 (tidak retak bila dilipat 4).

c. Uji gigit: 1 (sangat lembek), 3 (lembek), 5 (agak lembek), 7 (kekenyalan agak kuat spesifik produk), 9 (kekenyalan sangat kuat spesifik produk).

memiliki rasa yang enak dan menarik akan disukai oleh panelis.

\section{Penerimaan Keseluruhan}

Hasil sidik ragam menunjukkan bahwa penambahan ISP berpengaruh sangat nyata $(\mathrm{P}<0,01)$ terhadap penerimaan keseluruhan kamaboko ikan baramundi. Tabel 2 menunjukkan bahwa nilai rata-rata tertinggi diperoleh pada kamaboko perlakuan K2 $(5,93)$ dengan kriteria suka serta berbeda tidak nyata dengan K3 $(5,67)$, sedangkan nilai rata-rata terendah diperoleh pada kamaboko perlakuan K0 $(3,67)$ dengan kriteria biasa. Penerimaan keseluruhan kamaboko ikan barramundi dipengaruhi oleh faktor lain seperti warna, aroma, tekstur, dan rasa. Nilai rata-rata dengan kriteria suka tersebut menunjukkan bahwa produk kamaboko ikan barramundi dapat diterima oleh panelis.

\section{Kenampakan}

Hasil sidik ragam menunjukkan bahwa penambahan ISP berpengaruh tidak nyata pada kenampakan kamaboko ikan barramundi $(\mathrm{P}>0,05)$. Tabel 3 menunjukkan bahwa nilai rata-rata dari uji skoring kenampakan kamaboko ikan barramundi berkisar antara 8,47 sampai 8,87 yang berarti berada pada kriteria daging tanpa serat, tanpa benda asing. Nilai tersebut menujukkan bahwa produk kamaboko ikan barramundi yang dihasilkan sudah memenuhi SNI 2694:2013 dengan minimal skor yang dihasilkan adalah 7 . 


\section{Uji Lipat}

Hasil sidik ragam menunjukkan bahwa penambahan ISP berpengaruh sangat nyata pada uji lipat kamaboko ikan barramundi $(\mathrm{P}<0,01)$. Tabel 3 menunjukkan bahwa nilai rata-rata dari uji skoring uji lipat kamaboko ikan barramundi tertinggi pada perlakuan K4 (16\%) yaitu 8,87 dan skor terendah pada perlakuan K0 (0\%) 1,27. Skor uji lipat kamaboko berkaitan dengan tektstur kamaboko yang dipengaruhi oleh penambahan ISP dengan konsentrasi tertentu sehingga produk dengan penambahan ISP yang tinggi akan mengakibatkan struktur produk lebih kompak dan tidak patah apabila dilipat. Kamaboko K0 yang dihasilkan akan patah seluruhnya apabila dilakukan uji lipat, sementara pada K4 tidak mengalami keretakan apabila dilipat 4 . Berdasarkan nilai rata-rata uji lipat kamaboko maka produk yang memenuhi SNI 2694:2013 adalah produk dengan perlakuan K2 (8\%), K3 (12\%), dan K4 (16\%) dengan skor minimal 7.

\section{Uji Gigit}

Hasil sidik ragam menunjukkan bahwa penambahan ISP berpengaruh sangat nyata pada uji gigit kamaboko ikan barramundi $(\mathrm{P}<0,01)$. Tabel 3 menunjukkan bahwa nilai rata-rata dari uji skoring uji gigit kamaboko ikan barramundi tertinggi pada perlakuan K4 (16\%) yaitu 8,87 dan skor terendah pada perlakuan K0 (0\%) 2,20. Skor uji gigit kamaboko berkaitan dengan tektstur kamaboko yang dipengaruhi oleh penambahan ISP dengan konsentrasi tertentu yang mempengaruhi kadar air kamaboko sehingga strukturnya menjadi kompak dan juicy ketika digigit seiring dengan peningkatan penambahan ISP. Kamaboko K0 yang dihasilkan memiliki kriteria lembek, sementara pada K4 kamaboko yang dihasilkan memiliki kekenyalan sangat kuat spesifik produk. Berdasarkan nilai rata-rata uji gigit kamaboko maka produk yang memenuhi SNI 2694:2013 adalah produk dengan perlakuan K3 (12\%) dan K4 (16\%) dengan skor minimal 7.

\section{KESIMPULAN DAN SARAN}

\section{Simpulan}

Berdasarkan hasil penelitian ini dapat disimpulkan sebagai berikut :

1. Penambahan ISP pada pembuatan kamaboko ikan barramundi berpengaruh sangat nyata terhadap tekstur (kekuatan gel), kadar air, kadar protein, kadar abu, uji hedonik (warna, tekstur, rasa, penerimaan keseluruhan) dan uji skoring (uji lipat dan uji gigit).

2. Penambahan ISP $12 \%$ merupakan karakteristik terbaik dengan nilai kekuatan gel 1404,76 gf $/ \mathrm{cm}^{2}$, kadar air 74,42\%, kadar protein $15,40 \%$, kadar lemak 3,64\%, kadar abu 3,55\%, warna, tekstur, rasa, dan penerimaan keseluruhan disukai, aroma agak suka, kenampakan daging tanpa serat dan tanpa benda asing, uji lipat tidak retak bila dilipat 4 kali, dan uji gigit kekenyalan agak kuat spesifik produk.

\section{Saran}

Berdasarkan hasil penelitian ini disarankan untuk:

1. Pembuatan kamaboko ikan barramundi sebaiknya digunakan ISP sebagai emulsifier sebanyak $12 \%$ dan dilakukan pengujian masa simpan kamaboko ikan barramundi dengan penambahan ISP.

2. Dilakukan penelitian mengenai frekuensi pencucian surimi pada pembuatan kamaboko ikan barramundi dan digunakan mesin pengepres untuk mengepres surimi yang sudah dicuci agar kadar air yang dihasilkan tidak terlalu tinggi. 


\section{DAFTAR PUSTAKA}

Afrianto, E. dan E. Liviawaty. 2005. Pengawetan dan Pengolahan Ikan. Kanisisus, Yogyakarta.

Anonimus. 2013. Standar Nasional Indonesia 2694:2013 Surimi. Badan Standar Nasional Indonesia, Jakarta.

Anonimus. 2018a. Produktivitas Perikanan Indonesia. Kementrian Kelautan dan Perikanan Indonesia, Jakarta.

Anonimus. 2018b. Kamaboko. https://restaurants guide tokyo. Diakses pada 12 September 2018.

Astuti, R. T. 2014. Pengaruh penamabahan isolat protein kedelai terhadap karakteristik bakso dari surimi ikan swagi (Priacanthus tayenus). Jurnal Pengolahan dan Bioteknologi Hasil Perikanan. 3(3): 47-54.

Chung, K. H. dan C.M. Lee. 1991. Water binding and ingredient dispersion pattern effects on surimi gel texture. Journal of Food Science 56: 1263-1266

Fennema, O. R. 1976. Principles of Food Science Part 1 Food Chemistry. Marcel Dekker Incorporation, New York.

Forrest, J. C, E. D. Aberle, H. B. Hedrick, M. D. Judge dan R. A. Markel. 1975. Principles of Meat Science. W.H. Freeman and Co, San Fransisco. Hamdani, M. 2015. Karakterisasi Surimi Segar Ikan Lele Dumbo (Clarias gariepinus) dan Aplikasinya Untuk Pembuatan Kamaboko. Skripsi. Fakultas Teknologi Pertanian. Institut Pertanian Bogor, Bogor.

Jafarpour, A, H. A Hajiduon, M. Rez aie. 2012. A Comparative study on effect of egg white, soy protein isolate and potato starch on functional properties of common carp (Cyprinus carpio) surimi gel. Journal Food Process Technology 3:190. Kamruzzaman, M. D. Hossain, M. A. S. Jewel, D. A. Khanom, S. Mustary dan M. M. Khatun. 2015. Proximate composition and nutritional value of different life stages of Lates calcarifer (Bloch, 1790). Jurnal Zoological Universitas Rajshahi Bangladesh 34: 21-24.

Koswara, S. 2009. Teknologi Pengolahan Kedelai (Teori dan Praktek). www.EbookPangan.com. Diakses pada 12 September 2018.

Lanier, T. C. 1992. Measurements of Surimi Composition and Functional Properties in Surimi Process Technology. Marcel Decker Inc, New York.

Latifa, B. N. 2014. Pengaruh penambahan karaginan, egg white powder dan isolat protein kedelai terhadap kualitas gel surimi ikan kurisi (Nemipterus nematophorus). Jurnal Pengolahan dan Bioteknologi Hasil Perikanan 3 (4): 89-97.

Midayanto, N. Y. dan S. S. Yuwono. 2014. Penentuan atribut mutu tekstur tahu untuk direkomendasikan sebagai syarat tambahan dalam standar nasional Indonesia. Jurnal Pangan dan Agoindustri 2(4): 259-267.

Park J.W. 2005. Surimi and Surimi Seafood. Second Edition. Food Science and Technology. Taylor \& Francis Goup, New York.

Park, J.W. dan M.T. Morrissey. 2000. Manufacturing of surimi from light muscle fish. Marcell Decker, New York. 
Pradana, Y. A. 2008. Peranan Tepung Daun Jambu Biji (Psidium guajava) Terhadap Kemunduran Mutu Fillet Ikan Nila (Oreochromis niloticus). Skripsi. Fakultas Perikanan dan Ilmu Kelautan. Institut Pertanian Bogor, Bogor. Sari, S.M. 2016. Perbandingan Tepung Sorgum, Tepung Sukun, dengan Kacang Tanah dan Jenis Gula terhadap Karakteristik Snack Bar. Skripsi. Program Studi Teknologi Pangan Universitas Pasundan. Bandung.

Sari, S.M. 2016. Perbandingan Tepung Sorgum, Tepung Sukun, dengan Kacang Tanah dan Jenis Gula terhadap Karakteristik Snack Bar. Skripsi. Program Studi Teknologi Pangan Universitas Pasundan. Bandung.

Soekarto, S. T. 1985. Penilaian Oganoleptik untuk Industri Pangan dan Hasil Pertanian. Bharatara Karya Akasara, Jakarta.

Steel, R. G. D. dan J. H. Torrie. 1993. Prinsip dan Prosedur Statistika Suatu Pendekatan Biometrik. Penerjemah B. Sumantri. PT. Gramedia Pustaka, Jakarta. Sudarmadji, S., B. Haryono., dan Suhardi. 1997. Prosedur Analisa untuk Bahan Makanan dan Pertanian. Liberty, Yogyakarta.

Sudarmadji, S., B. Haryono., dan Suhardi. 1997. Prosedur Analisa untuk Bahan Makanan dan Pertanian. Liberty, Yogyakarta.

Suryanto, E. 2011. Pengguanaan protein kedelai pada industri olahan daging. http://foodreview.co.id/-56553-

Penggunaan Protein Kedelai pada IndustriOlahan Daging.html. Diakses pada 07 September 2018.

Suzuki, T. 1981. Fish and Krill Protein Processing Technology. Applied Science Publishers Ltd, London.

Tarwiyah. 2001. Budidaya Ikan. Baung, Jakarta.
Utomo, A. 2014. Aplikasi Alginat sebagai Emulsifier didalam Pembuatan Kamaboko Ikan Kuniran (Upeneus sulphureus) pada Penyimpanan Suhu Ruang. Skripsi. Fakultas Perikanan dan Ilmu Kelautan, Universitas Diponegoro, Semarang.

Widodo, S. A. 2008. Karakteristik Sosis Ikan Kurisi (Nemipterus nematophorus) dengan Penambahan Isolat Protein Kedelai dan Karagenan pada Penyimpanan Suhu Chilling dan Freezing. Skripsi. Fakultas Perikanan dan Ilmu Kelautan. Institut Pertanian Bogor, Bogor.

Winarno, F. G. 1997. Kimia Pangan dan Gizi. PT Gramedia, Jakarta. Winarno, F. G. 2004. Hasil-hasil Simposium Penganekaragaman Pangan. Prakarsa Swasta dan Pemda, Jakarta.

Winarno, F. G. 2004. Hasil-hasil Simposium Penganekaragaman Pangan. Prakarsa Swasta dan Pemda, Jakarta. 